\title{
Lexico-semantic field of the concept "power" (based on the material of "Domostroy" and "The legend of princess Olga")
}

\author{
Oksana Vyacheslavovna Popova* \\ Omsk Humanitarian Academy, 4-ya Chelyuskintsev street, 2a, 644105 Omsk
}

\begin{abstract}
Quite a large number of linguistic works are aimed at understanding the essence of power, the main task of which is to reconstruct the perception and attitude to power. This article attempts to analyze the lexical and semantic field of the concept "POWER", with special attention paid to the meanings of the word "power". The illustrative material is the Dictionary of the Russian language, as well as the Old Russian texts "Domostroy" and "The Legend of Princess Olga". The description of the lexical and semantic field of the concept of "Power" based on the material of these texts allows one to identify the initial ideas about the phenomenon of power.
\end{abstract}

\section{Introduction}

Like any phenomenon of human life, power has always been the object of a significant number of researchers' attention. Today, there are different approaches to understanding power, partly due to the fact that the semantics of the word power is extremely variable, closely related to such concepts as "state", "influence", "domination", "strength", etc. In this regard, the study of the lexical and semantic field of the concept of "POWER" will allow one to consider the historically changing structure of semantic relations of concepts that come into contact with the perception of power. In order to understand the deep meanings of the word, it is necessary to consider the history of the native lexemes' origin. The above-mentioned definitions denote the perception and attitude to the power of society at the stages of its formation and reflect the historically changing idea of the people about state unity and state power, and the development of the Russian state. Referring to the Dictionary of the Russian language, one can distinguish the following meanings of the word power:

1 'The right to govern the state, political domination, rights and powers of state bodies'. 2. 'Public administration bodies, government, officials, superiors'. 3. 'The right and ability to command, rule, or control someone or something'. 4. 'Strength, dominion, power'. Your power - as you please, your business. In my (your, his, etc.) power - 'depends on me, concerns me'. In power or under power - 'under effect, under influence'. To surrender to power, to surrender or indulge in power - 'to submit to someone or something, to be influenced by someone or something'. To lose control over oneself - to 'lose self-control'. The verb to rule is used in the meanings of 'to govern, to rule (a country, a state), subjugating to one's will; to

* Corresponding author: tischka2001@mail.ru 
dispose of someone or something, to govern, to exert influence, to subordinate to one's influence' [10: 91].

2. In the Proto-Slavic language, the word power and volost, which had the meanings 'region, territory, state, power', were parallel forms - from Proto-Slavic *vold- Old Slavonic power (Bulgarian vlast, Serbo-Croatian vlast, Slovenian vlast meant 'possession', 'property', Czech vlast and Slovak vlast - 'homeland', Polish wlosc, Latvian valsts, Lithuanian valscious - 'volost'. These meanings were also given to the verb volodti [11: 344].

3. In the XI-XVIII centuries, the meaning of the word power was, in fact, the same as today, the historical meaning of it - 'country, state, region, possession'. In particular, the Dictionary of the Old Russian Language (XI-XIV centuries) [7: 444-446] gives the following meanings of the word power: 1 . 'Region, principality, state. The population of a certain territory, organized in the form of a detachment, troops'. 2. 'Possession, ownership'. 3. 'Power, dominion, signory. 4 . The right, the ability to do something. 5. Plural 'Persons in power'.

Similar meanings are given by the Dictionary of the Russian Language of the XI-XVII centuries [8:221-222]: 1. 'Power, dominion, supreme power, government, signory, the activities of the governor, the administrator, the official administrative person, who are in charge, who dispose of something in the field'. 2. 'Authorities, ecclesiastical and civil persons invested with power'. 3. 'A region under one supreme authority (principality, shire, parish)'. 4. 'Authority, opportunity, the right to act at will'. The verb vlastvovati was used in the following meanings: 1 . To reign supreme, to rule, to operate. 2. To dominate, to prevail [9: 216], and also "to be peculiar, inherent in someone" [9: 202-203].

The presented chain of the concept's meanings "POWER" was built up gradually, it is on the basis of this sequence that it is possible to identify the semantic depth of the original root, which turned out to be able to generate many meanings.

\section{Materials and methods}

In this article, we used the descriptive method of the lexical-semantic field of the concept "POWER", which is characterized by a hierarchical organization of meanings that are included in the concept and add particular meanings to it, not only in terms of content, but also in terms of expression.

The material for this study was the dictionaries of the Old Russian language and the Dictionary of the Russian Language, which reflect the codified meanings of the word "power". The choice of the Old Russian texts "Domostroy" and "The Legend of Princess Olga" is not accidental, since it is in these works of Old Russian literature that the foundations of the perception of power as such are laid. Turning to the study of "The Legend of Princess Olga", it is important to note that this work is part of the "Staid Royal Genealogy" (in scientific usage - "The Staid Book"), the main purpose of which is to form ideological ideas about the origins and meaning of power. The central idea of "The Staid Book", which includes the "Legend", is to present Russian history as the acts of the holy Moscow sovereigns and their ancestors. As D.S. Likhachev notes, "if earlier in the chronicle narrative the discontinuity and jumps from one episode to another were supposed to portray the insignificance of what is happening in this world in contrast to the significant - eternity, now it is time when the opposite was emphasized - the significance of everything that is happening in this world. If earlier the past was presented as a kind of events scattering, and historical writings presented history in fragments, then in the XVI century, history sought to turn into a coherent and plot narrative" [5: 9]. It is in "The Staid Book" that great importance is paid to the origin of the tsarist power in Russia, through the endowment of princes with such qualities as wisdom and piety, unquestioning submission to the legitimate power is formed, and the connection between secular and ecclesiastical power is emphasized. 
In the center of "The Staid Book" narrative is a description of the personalities of the princes, combining personal history with the history of Russia.

\section{Results and discussions}

It should be noted that in "The Legend of Princess Olga" the main attention is paid to the character traits of the princess, her actions "...многа блага о бозЬ содЂвая, и всЪми добрыми дЂль освящашеся и милостынею обогащашеся: нагие одЂвая, алчныя напитая, жадныя напаяя и странныя упокоивая всяким благопотребством" [3: 280]. In this work, a limited number of words are used that are thematically related to the conceptual concept of power: domination, autocrat, sovereign, tsar, power holder. The word power was used only in one case - in the combination of royal power: "Внегда же прииде время, $и$ повелЂнию Игоря изобрЂсти ему невЂсту на бракъ, яко же есть обычай господьству и иарстей власти" [3: 250]; "Увы мнъ, свяЂтлЂйший самодержателю, великий государю русский!" [3: 250].

The use of the vocative forms of the autocrat, the sovereign, gives the narrative a high tone, since in the XVI century this form gradually begins to be lost. It should be noted that the expression of royal power was a bold innovation of the authors of "The Staid Book", since previously the forms of addresses tsar, sovereign, autocrat in relation to princes were not used: these forms began to be used regularly only since the time of Ivan III (mainly in diplomatic texts). "Vasily III, who succeeded Ivan III, was content with the old title of "Grand Duke". His son Ivan IV the Fearsome was crowned King of All Russia when he came full age (1547), thus establishing his prestige in the eyes of his subjects as a sovereign ruler and heir to the Byzantine emperors (abroad, his title was either not recognized or left without translation)" [1: 67].

In addition to the above-mentioned appeals, the word "power holder" is found in the text of the "Legend":

"Убийцам супруга своего Ольга месть возда, яко же властодержателие обычай uм xyy [p.258]. In this case, the word has a broad meaning of 'having power'. It should also be noted that the author of the text always makes an amendment to the custom or tradition, if he tells about the pagan rites of the princes:

"И ина многа плачевная притворяме глаголы и повель могилу сыпати надъ Игорем и тризны творити, яко же есть обычай в невБрныхх" [3: 256].

The earlier meaning of the word power - 'region, principality, possession of property' - is also presented in the text of the "Legend". [7: 444-446], while the attribute of possession is explicated mainly in verb forms:

"Игорь повоева страны Финическия и по Понту, и до Ираклия ... всю Никомидийскую землю полони" [3: 256]. Verbs presented in the form of an aorist (роvоеvа and poloni)) have the general meaning of 'to conquer, to subordinate to your will'. In this case, power is the possession of lands that are subject to the princely will.

In contrast to "The Legend of Princess Olga" in "Domostroy", also created in the XVI century, the century of generalization and unification, painted estates with power:

a) the veneration of representatives of the royal power and those close to it, for example, princes, nobles:

"Царя бойся и служи ему върою ... ложно не глаголи предъ нимъ, но с покорениемъ и во всем повинуйся ему" [2: 74];

"Тако же и княземь покоряйтесь и должную ему честь воздавай, яко от него посланомь во отмщение злодЂем", "В похвалу же добродЂемъ князю своему прияйте всЂмъ сердиемъ, и властителемъ своимъ; ни помыслите на ня зла", "Аще кто противится властителемъ, то божию повЂлению противица, а йарю, и князю и всякому велможе и клеветою, и лукавствомъ" [2: 76]. 
It should be noted that in "Domostroy" the security functions of people with power are differentiated. The tsar is the vicegerent of God on earth, who must teach his subjects to honor both the earthly and the divine tsar. The prince is sent by God to "punish the villains". A simple person should accept power from the "rulers" and "nobles" with all his heart. In the dictionary of the Old Russian language (XI-XIV), the ruler has a broader meaning of 'having power', and the nobleman - 'a noble person, close to the prince or tsar'.

b) veneration of representatives of the spiritual authority:

"Како чтити отиевъ своихъ духовных, подобает чтити и повиноваться ему во всемъ и каяться пред нимъ со слезами извъщайтися всегда во всякой совести и наказание его с любовию приимати" [2: 84];

c) veneration of elders and parents:

"старейшимъ себЂ честь воздавай и поклонение твори, среднихъ яко братию почитай, маломощныхх и скорбных любовию привъчай, юнейших яко чада люби" [2: 76]. ". Любите отиа своего и матерь свою и послушайте их, и повинуйтеся имъ по бозБ во всемъ ... Аще кто злословить или оскобляеть родителя или кленеть или лаеть, $\underline{\text { сий }}$ предъ богом грЂшенъ от народа проклять,... аще кто биеть отиа или матерь - от иеркви и оть всякия святыни да отлучится и лютою смертию и градскою казнью да умрет!" [2: 88].

Any disobedience to the prescribed rules entails more punishment of God, the innocent is excommunicated from the church, he is cursed by the people, he can be subjected to public execution. This submission to authority is regarded as a blessing. At the same time, the following observation is significant: regardless of the object of worship (tsar, prince, nobleman, elders or parents), in the "Domostroy", action is transmitted in similar imperative forms (честь воздавай, поклонение твори, подобает чьтити и повиноватися).

Essential to the semantic field of the concept is the fact that in "Domostroy" for the first time the perception of power as violence is mentioned:

"А кто не по християнскому житию чинит всякую направду и насилие..., кто не добрь или в сель на своихъ християнъ или на приказе, или на власти дани тяжкие накладывает...и всякое угодье неправдою и насилиемъ сотворит или ограбит или насилиемъ охолопить будеть проклят..." [2: 102].

The very form of violence is relatively new, since in the dictionary of the Old Russian language (XI-XIV), the meaning of "to force, to put pressure on someone" was inherent in the word force. In this case, power can be understood as an illegal manifestation of force.

Closely related to the subject of subordination are the nominative forms denoting social position. There are the following nominations in "Domostroy" for people who have the right to exercise power:

- monarch and monarchess: In the dictionary of Dal, monarch has the meaning of 'secular ruler, supreme head of the country, sovereign person': "Какое питье носити про государя и государыни и про семью... все чинити и дълати и отдавати по государеву наказу" [2:140].

In "Domostroy", this word can equally mean both the supreme head of state and an influential person. "The word monarch comes from the ancient gospodar - an ancient Slavic word with the same meaning as the collective the God, Gods, but only in relation to the worldly subject of action. The sovereign is at the head of the state at first simply as the master, the owner of his estates, he is the lord, that is, in the sense of the original word, it is the God. All the free members of society subject to him are also sovereigns, but this time in relation to lower degrees of social rank, which in turn are called by the same word, but already in a household abbreviation: not the sovereign, but the ruler" [4: 171].

- a special place in "Domostroy" is occupied by servants who have the right to observe and monitor the serfs, they include the clerk, the butler, the housekeeper. 
"Приказному человеку, дворецкому или ключнику, или купчине на комъ вБра положена или самому государю всегда в торгу смотрите всяково запасу" [2: 124].

The word butler has the meaning of 'senior servant in the house, head of the household and servants'. Since the XVII century, the word denotes a yard title, and even later it is used in the meaning of 'manager of the economy in landowners' estates and city mansions in Russia'. In contrast to the previous word jemadar with the meaning of "hired person at a merchant or in some commercial institution, who performed errands of a commercial nature, engaged in trade in the store by proxy of the owner" in Old Russian dictionaries is not found, which may indicate a later occurrence of this word, however, in "Domostroy" the nomination jemadar is also used:

".. и у торговиовъ, и у всякихъ своихъ прикашиковъ всегда всего пересматривати и пытати..." [2: 152].

The general meaning of key-keeper token is 'an employee who was in charge of the food supplies of the house, family and carried the keys to the places where they were stored'. If we turn to the etymology of this word, it turns out that it arose as a result of the metonymic transfer of the meaning 'to walk taking keys or with keys'.

Nominative forms denoting people of lower social status include:

- servant, the most common and frequent: "Всяку человеку, государю или государыни, или служке мужеска полу и женьска ..." [2: 90]. "А по вся дни государыня у слугъ дазираетъ, которые пекуть и варять" [2: 112]. The general meaning of this word, represented in the monument, is 'a worker in a rich house for personal services'.

- the synonymous categories in "Domostroy" include the forms домочадиь and domestics, since in the text they are found in the same context: "Государю ижену, и дътей, домочадиовъ своихъ учити не красти, не блясти не солгати...' [2: 92]; "От таких домочадиовъ богатеют мужи" [2:112]; "Как прежде писаному дворовымъ людямъ от государя бережение пожаловати..." [2: 112]; "А людей у собя добрыхъ дворовыхъ держати, чтобы были рукодельны" [2: 92].

The word housemates means 'people who live in someone's family on the rights of its members'. Domestics were the persons who formed the yard staff of the Russian princes, great and specific, in Ancient Russia, which greatly expanded under the Moscow Grand Duke and reached its highest flourishing under the "sovereign, tsar and Grand Duke of Moscow and all Russia". "The yard people, in the absence of strict distinctions in the state system of ancient Russia, were not exclusively courtiers or managers of the private affairs of the Grand Duke and the tsar of Moscow; they performed various administrative, judicial and military positions. The composition of the "yard" included: key-keepers, solicitors, sytniki, podklyuchniki; clerks, grooms, stirrups, solicitors, etc." [6: 99].

It can be assumed that both words in "Domostroy" are used in the more general sense of "belonging to or relating to a house or yard". Moreover, this monument, obviously, describes for the most part the house of the prince or directly the sovereign's yard, since it lists the courtyards that were related to the sovereign.

- the most rare category of dependent people-valetry: "Ключнику наказывати как челядь кормить по вся дни.." [2:142]. "Наказ от государя повару... варить на семью челяди и нисшимъ скромную и постную еству" [2:142].

The word valetry in Ancient Russia VI-X centuries. was used to refer to slaves. They were completely disenfranchised. People who became slaves for other reasons were called bondmen. The sources of servitude were: self-sale, marriage to a slave "without a row", the entry of "without a row" into the position of tiun or housekeeper. .In the XVIII-XIX centuries the word "valetry" meant the yard people of the landowner. 


\section{Conclusion}

Summarizing the conducted research, we can preliminarily conclude:

1. The lexical and semantic field of power in the presented monuments is modeled by the following meanings: 'possession of territories, the state', 'the right to dispose, command, manage someone, something', 'power, domination, power'.

2. The lexical and semantic field of the concept "POWER" includes nominative forms that denote the social position in which the degree of possession of power is laid down. In this connection, it is possible to build a semantic chain according to the degree of "decreasing" power: monarch (the God)- henchman-house-steward-key-keeper-servant-domestics - bondman-valetry.

3. At the grammatical level, this topic is updated in the imperative forms of verbs and in the preservation of vocative forms.

4. The use in "The Staid Book" of new forms of addresses: tsar, sovereign, autocrat, power holder in relation to princes can serve as proof that the lexical and semantic field in the field of nominations of persons with power is expanding.

\section{References}

1. A. A. Gorsky, On the title "Tsar" in Medieval Russia (until the middle of the XVI century), A man in history (1996)

2. Domostroy, ed. L. A. Dmitrieva, D. S. Likhacheva, Artifacts of literature of Ancient Russia: The middle of the XVI century, 638 (1985)

3. From "The Staid Book", The Legend of Princess Olga, ed. L. A. Dmitrieva, D. S. Likhacheva, Artifacts of literature of Ancient Russia: The middle of the XVI century, 638 (1985)

4. V. V. Kolesov, Ancient Russia: Heritage in the Word, Good and evil, 2, 240 (2001)

5. L.A. Dmitrieva, D. S. Likhacheva, Literature of the state structure, Artifacts of literature of Ancient Russia: The middle of the XVI century, 638 (1985)

6. V. G. Ledyaev, Power: a conceptual analysis, Russian Political Encyclopedia (ROSSPEN), 384 (2001) http:/grachev62.narod.ru/

7. Dictionary of the Old Russian language (XI-XIV) centuries, 1 (1988)

8. Dictionary of the Russian language of the XI-XVII centuries, 2 (1975)

9. Dictionary of the Russian language of the XVIII century, 3 (1987)

10. Russian Dictionary in four volumes, 1 (1985)

11. M. Fasmer, Etymological dictionary of the Russian language, 2 (1986) 